\title{
Success without Design: Hallyu (Korean Wave) and Its Implications for Cultural Policy*
}

\author{
Jungsoo Kim**
}

\begin{abstract}
The huge popularity of Korean pop culture overseas, labeled Hallyu, otherwise known as the Korean Wave, is an unprecedented event in the cultural history of Korea. Many foreign observers tend to see it as the result of the Korean government's policy efforts. This paper claims that Hallyu in essence is an unintended "success without design." No one, including the Korean government, intentionally planned it. There were five key factors that made it possible: the competitiveness of Korean culture industries, political economic changes in East Asian countries, entrepreneurs in show business, fragmentary governmental support, and global digital networks. Each of these factors has independently contributed in its own way to the success of Hallyu. The fact that Hallyu is not a product of any deliberate plan has some important implications for cultural policy and culture industries.
\end{abstract}

Keywords: Hallyu, Korean Wave, Korean popular culture, cultural policy, culture industries

\section{INTRODUCTION}

Hallyu, otherwise known as the Korean Wave, refers to the global popularity of Korean popular culture since the 1990s. It has several important implications. For many Korean citizens, Hallyu has become a symbol of national pride. From a business point of view, it represents a quantum leap in the culture industries of Korea. Making Hallyu sustainable poses a serious challenge for Korean policy makers as well as entertainment companies. For those interested in cultural policy, it poses some interesting questions

\footnotetext{
* A draft of this paper was presented at the 9th International Conference on Cultural Policy Research held at Sookmyung Women's University, Seoul, South Korea, on July 7, 2016.

** Jungsoo Kim is a professor in the Department of Public Administration at Hanyang University, Seoul. E-mail: coramdeo@ hanyang.ac.kr.
}

Manuscript received September 30, 2016; out for review November 8, 2016; review completed December 2, 2016; accepted December 5, 2016.

The Korean Journal of Policy Studies, Vol. 31, No. 3 (2016), pp. 101-118.

(C) 2016 by the GSPA, Seoul National University 
regarding the relationship between cultural policy and cultural success.

This paper raises three research questions. Why does the cultural policy community need to pay a special attention to Hallyu? How can we explain the huge success of Hallyu? What are the implications of Hallyu for cultural policy and culture industries? The main arguments of this paper are as follows. Hallyu deserves special attention because in its success it can be compared to the miraculous takeoff of the Korean economy in the 1960s and 1970s. In this sense, Hallyu may well be called a cultural version of the "miracle on the Han River." Although there were several factors that contributed to the success of Hallyu, it was anything but a result of a carefully elaborated, concerted policy plan. In other words, Hallyu constitutes success without design. The success of Hallyu illuminates the limitations of cultural policy. We need to admit that the capabilities and responsibilities of the government are restricted.

\section{HALLYU, ANOTHER MIRACLE ON THE HAN RIVER}

Historically, Korea was peripheral state. During the 36 years of the Japanese colonial period, much of Korean tradition and culture was lost or compromised. The Korean War in 1950 devastated the Korean economy, leaving Korea one of the poorest and least developed countries in the world.

What changed the international image of Korea as a worn-torn country was the rapid economic and technological development that began the 1960s. The economic growth during the 1960s and 1970s was so impressive as to be dubbed the "miracle on the Han River." The digital revolution through the 1980s and 1990s further contributed to Korea's economic rise, turning it into the world's leading internet super power.

Hallyu in a sense is a cultural version of the miracle on the Han river. Culturally, Korea was not an influential country until quite recently. In ancient times, Korea used to import advanced culture from China. During the Japanese colonial period, Japanese culture partly influenced by Western culture was introduced to Korea. After the Korean War, American culture heavily influenced Koreans' way of life. Many Koreans were especially fascinated by the American popular culture, including pop music and Hollywood movies. Until the 1980s, Korean popular culture was so underdeveloped that it attracted no attention in the global market. Even most Korean youths preferred imported foreign culture. It was simply unimaginable then that one day Korea might compete on an equal footing with Japanese or American popular culture, both of which had firmly dominated the Korean domestic market.

Since the mid-1990s, however, Korean popular culture has become hugely influential not just at home but in neighboring Asian countries as well. Hallyu has arrived on the 
global cultural scene, challenging the virtual monopoly of American and Japanese (in Asia) popular culture (Kang, 2006, p. 104). Having sprung up first in the East Asian countries such as Taiwan, Vietnam, Hong Kong, and China, Hallyu soon spread out widely to other regions. Korean popular culture, especially K-pop and TV dramas, have been securing audiences in diverse areas of the world. Even Time magazine recognized that "Korean pop music, or K-pop, has crossing over into American markets" and reported that "Big Bang in particular ... have conquered Japan ... and won an MTV European Music Award in 2011, beating Britney Spears for Best Worldwide Act" (2012). The TV drama Winter Sonata, which aired in Japan from 2003 to 2004, led to the sensational "Yonsama" syndrome (a shortened form of the male star's name combined with -sama, an honorific conferring respect) especially among mid-aged Japanese women. Another drama DaeJangGeum (2003-2004) attracted many viewers in diverse areas of the world, including Islamic countries like Iran. Korean movies have likewise earned a global reputation by winning major awards at the Berlin, Cannes, and Venice international film festivals.

Korean popular culture nowadays has achieved the status of global big shot. Hallyu celebrities now enjoy huge popularity in the global market, sometimes surpassing the reputations of the top American or Japanese stars. That such neologisms as "K-pop" or "Hallyu" are commonly used worldwide is itself a significant indication of Korea's enhanced status in the global cultural scene.

In explaining the significance of Hallyu, Kang (2007, p. 274) emphasizes that "never in the history of Korea has our culture been so widely accepted in foreign countries." It is not an exaggeration to say that Korean culture had never crossed the country's borders and reached global consumers before Hallyu (Paik, 2005, p. 39). Some even contend that it is the most significant development in Korea "since the restoration of national independence" (Kang, 2006, p. 32). All in all, Hallyu is nothing less than "another Miracle on the Han River" (Kim, 2011, p. 4).

\section{FIVE KEY FACTORS BEHIND THE SUCCESS OF HALLYU}

Hallyu's origins can be traced back to 1996-1997, when the Chinese media first began to air Korean pop songs and TV dramas. K-pop in particular played a central role in initiating Hallyu in China. In 1996, some Chinese radio stations began to play Korean pop songs, which soon fascinated many culturally hungry Chinese teenagers. Among many Korean idol groups, H.O.T in particular enjoyed tremendous fandom in China. Their first album in China sold more than 50,000 copies in just one month, which far surpassed the local expectation that at most 5,000 might be sold. Moreover, 
their first concert at a 12,000-seat gym in Beijing in February 2000 became the first live concert ever held by foreign musicians in China to sell out (Chosunilbo, 2000, pp. 3, 6). A similar trend quickly emerged in other Asian countries like Taiwan, Vietnam, and Hong Kong. From that time on Hallyu soon began to spread to other regions of the world.

How did Hallyu happen? Five elements played key role.

\section{Internal Factor: The Competitiveness of Korean Popular Culture}

The most fundamental element that enabled the rise of Hallyu was the greater competitiveness of Korean popular culture, especially starting in the 1990s. Here the word "competitiveness" refers to cultural content that has the ability to capture people's minds and hearts. That cultural content has such a capacity does not, however, necessarily imply that it is being artistic, aesthetic, or sophisticated. And indeed Korean popular culture's artistry and originality have been criticized. But the point here is that Korean popular culture attracted the attention of many people around the world (Korea Creative Content Agency, 2011). It has a number of unique features that cannot be found in other domestic cultural markets. The dynamic dancing and singing of Korean idol groups, the touching stories and aesthetic visuals of Korean TV dramas, the lovely and stylish appearances of Korean celebrities enchant many foreign audiences.

The competitiveness of Korean popular culture is most evident in the case of K-pop (Ministry of Culture and Sports, 1997; Lee, 1998). After the restoration of national independence in 1945, the Korean music market was almost completely open to foreign music. There was practically no import barrier at all to protect Korean popular music. And the Korean government had not created any policy programs to support the country's domestic music industry (Kim, 1999). Until as late as the 1980s, the Korean popular music market and radio music programs were largely dominated by American pop music. Korean pop music was simply no match for the imported music from the West. Serious Korean music lovers tended to show contempt for domestic popular music.

However, the situation has now been reversed. K-pop not only managed to survive but to build up its own strength so as to take the lead in the domestic market (Yang, 1998). The market share data illustrated in figure 1 clearly shows this trend. In 1993, K-pop beat Western pop music by $64 \%$ to $23 \%$. The gap continued to grow. In 2004 , K-pop held as much as $80 \%$ of the Korean record market while Western pop took only $17 \%$.

The same goes for both Korean soap operas and movies, although the extent of their popularity is somewhat less dramatic than that of K-pop. Korean TV dramas used 
Figure 1. Market Share in the Korean Music Industry

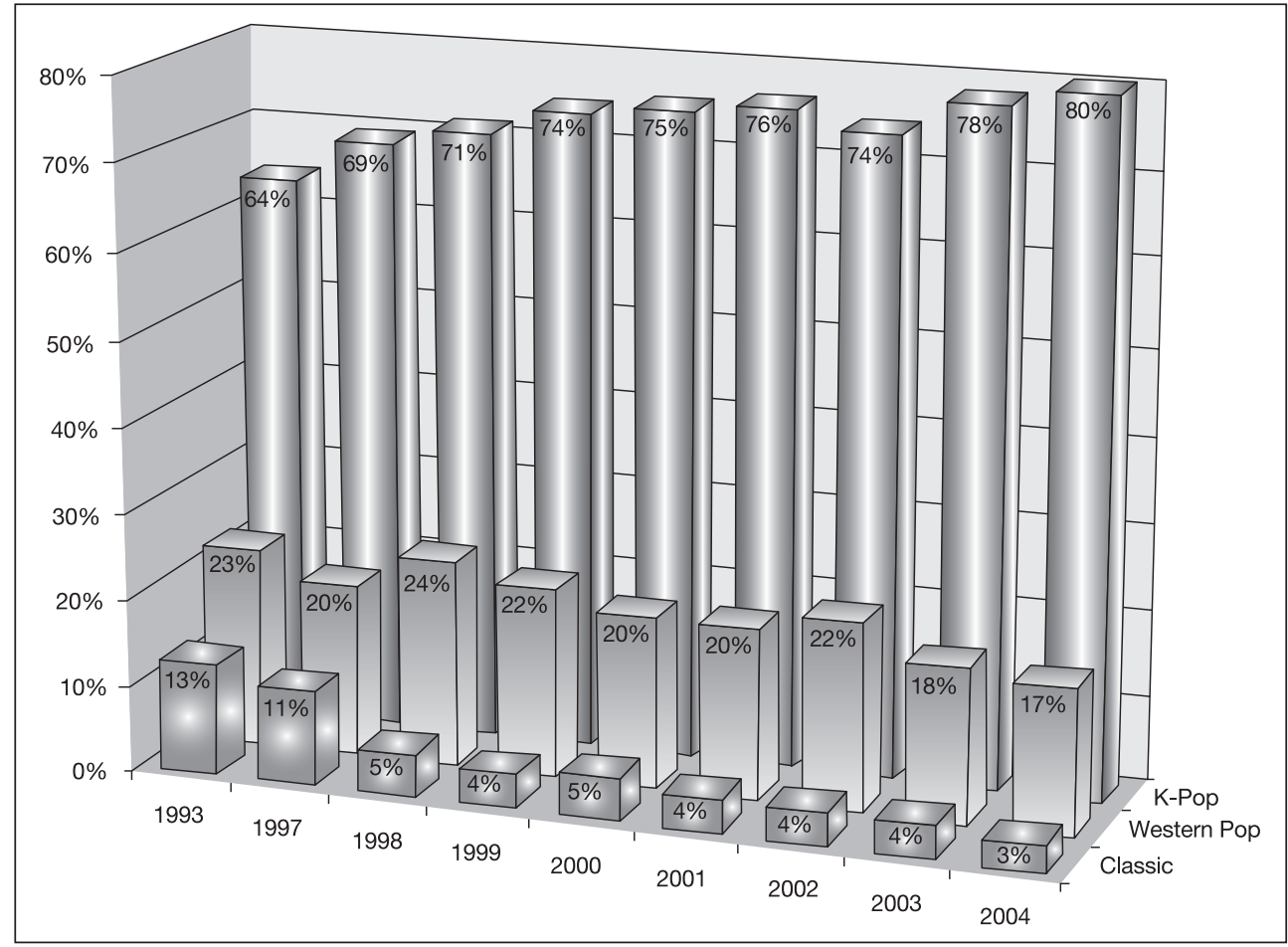

Source: Records Industry Association of Korea (www.riak.or.kr)

to be severely criticized for their hackneyed stories. Foreign TV programs imported mostly from the United States were very popular among Korean viewers. However, Korean broadcasting companies and producers began to compete fiercely with each other for higher viewer ratings. The harsh struggle for survival in a sense functioned as a tough drill camp that forced broadcast companies to experiment with various methods, content, and stories. Out of this process came such wonderful mega hits as Winter Sonata and DaeJangGeum. Figure 2 shows a dramatic increase of the export of Korean TV programs since the late 1990s.

So the first conclusion is that Hallyu would not have been possible if Korean popular culture was not attractive. K-pop in particular played a pivotal role, thanks to the remarkable growth of the Korean pop music industry (Korea Cultural Policy Institute, 2001). The building up of Korean popular culture's competitiveness in the domestic market was the key instigator of Hallyu. 
Figure 2. Export and Import of TV Programs

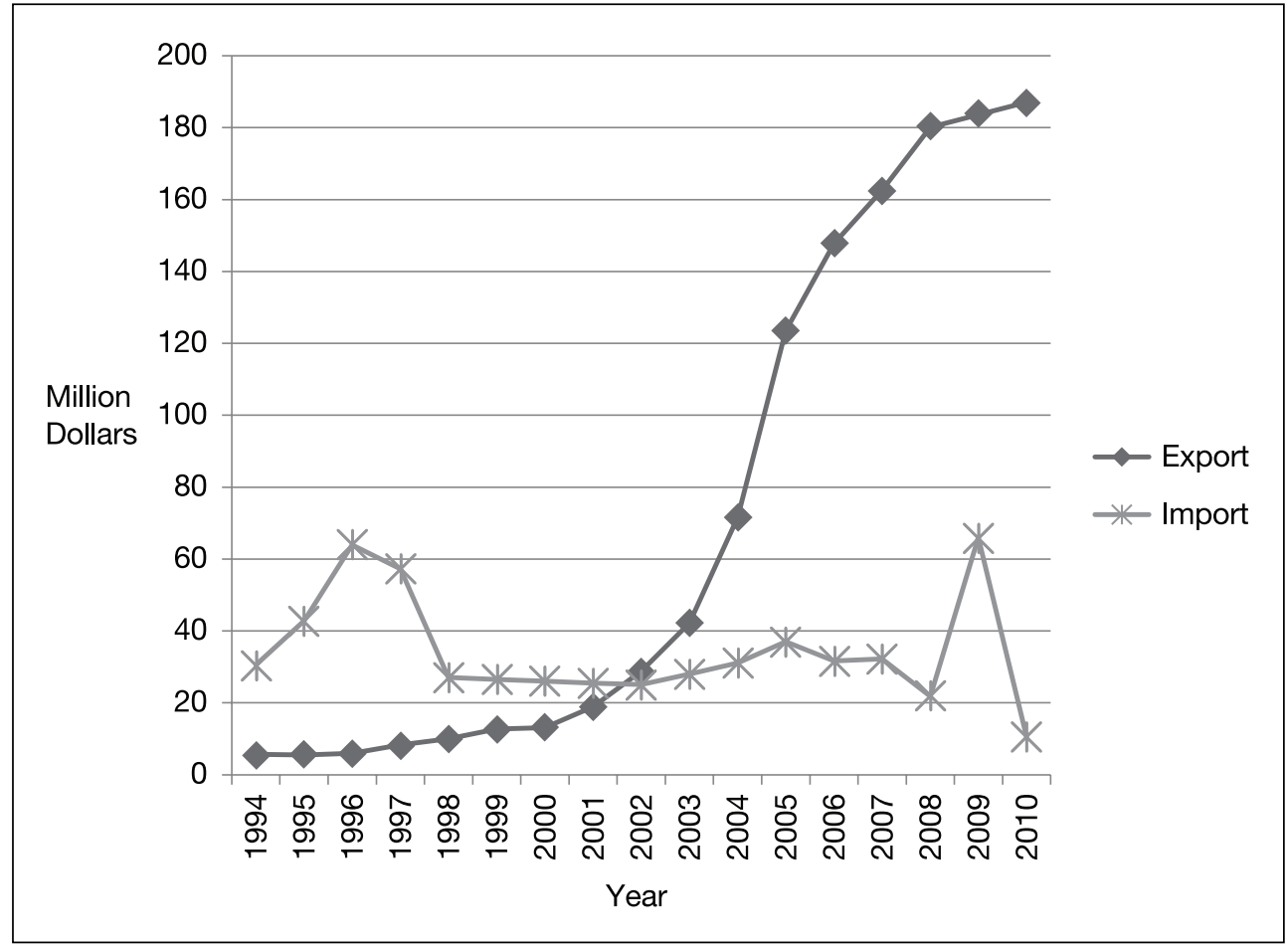

Source: Statistics Korea (http://kostat.go.kr/portal/eng/index.action)

\section{External Factor: Political and Economic Changes in East Asia}

The second factor was the political and economic changes in the East Asian countries. Rapid economic development, political democratization, and liberalization in this region have naturally brought increased consumer demand for popular culture, particularly among younger generations. But the local cultural industries could not deliver content that satisfied their youths, and so a "cultural vacuum," was created that functioned as another driver in the formation of Hallyu.

This was particularly true in China and Vietnam, where the governments used globalization as a strategy to encourage their economic development. As their economies grew, so did the desire for cultural consumption on the part of their people. But while demand increased sharply, supply by local producers in those countries lagged far behind in terms of both quantity and quality. Not interested in their own popular culture, many youngsters sought something new and exciting. This cultural vacuum was filled by the newly imported Korean popular culture, whose attractiveness 
had already been proven in the Korean domestic market.

China played a critical part in the initial stages of Hallyu. The economy of China has continued to grow significantly since the 1980s. As illustrated in figure 3 , the average annual growth rate of the Chinese GDP was as much as $9.8 \%$ during the 1980s and 1990s. During the same period, per capita GDP increased at almost the same rate, $8.4 \%$ on average annually. In conjunction with a huge population, China's rapid economic development has vastly expanded its domestic market. New groups of people appeared who made fortunes in big cities. During the period of rapid growth, the Chinese government imposed a strict policy aimed at controlling the birth rate and permitted most Chinese families to have only one child. These wealthy youngsters became more liberal and open because they had a lot of contact with foreign cultures. Chinese popular culture at that time could not satisfy their cultural hunger. The popular culture of Korea did.

Why then was it Korean, rather than American or Japanese, popular culture that swiftly filled this cultural vacuum? Despite economic liberalization and globalization, China and Vietnam are still under communist governments. So it would be uncomfortable for them to see their citizens in the thrall of a popular culture with such a capitalist flavor. Further, East Asian countries still reject Japanese culture due to the bitter memories of the brutal Japanese imperialism in the past. In light of this, Korea has a kind of comparative advantage. The popular culture of modern Korea is hybrid; it was originally imported from America and significantly influenced by the Japanese style. Yet traditional Confucian ideas are still preserved in it. In other words, Korean popular culture is appealing like American and Japanese culture while being less detrimental from the perspective of the Chinese and Vietnamese governments. If either had

Figure 3. Economic Growth of China

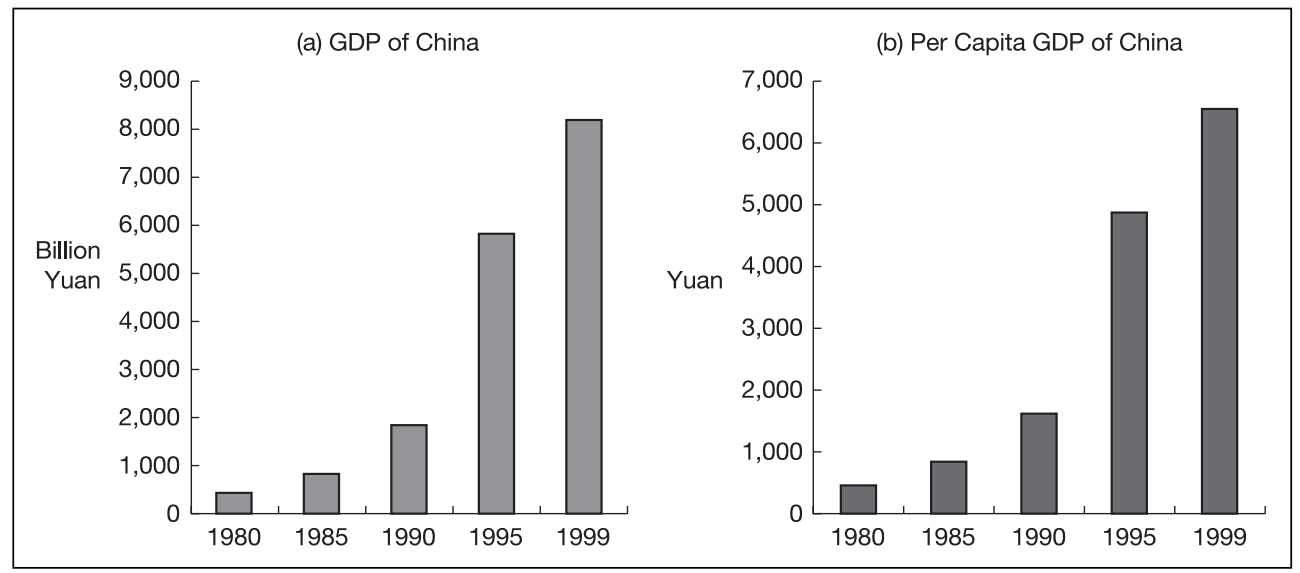

Source: World Bank (http://data.worldbank.org/country/china) 
deemed Korean pop culture unacceptable, Hallyu could not have taken root there (Ryu, 2001).

\section{Individual Factor: Entrepreneurs in Show Business}

No matter how competitive Korean popular culture was, and no matter how culturally hungry East Asian consumers were, Hallyu could not have occurred without the effort of a few individuals who worked very hard to export Korean pop culture to foreign markets. One such pioneer was Yun-ho Kim, the president of Woojeon Soft. In the mid-1990s, he started introducing Korean pop music to China through several radio programs, including the Beijing music station, the Traffic station, and the Commercial music station (Lee, 2000). After spending several years in China, he came to the conclusion that Korean dance music could be a hit in China because of its distinctive difference from Hong Kong and Taiwanese music, which at that time was mostly ballad oriented. He reckoned that the strong beat and rhythm of dance music could make up for the fact that the Korean lyrics would not be understood by Chinese speakers. He put a lot of effort into advertising K-pop in China.

Another pioneer was Soo-man Lee, the CEO of SM Entertainment, which was Korea's first listed corporation in show business (Yoo et al., 2005). He was the man who introduced many top stars like H.O.T, S.E.S, Shinhwa, Boa, Super Juniors, Girls Generation, Shinee, and EXO. Once a very popular singer in the 1970s, Lee had a lifelong dream of seeing Korean singers enthusiastically hailed by foreign audiences. After studying computer science in the United States, he came back to Korea with an ambitious plan to launch a major entertainment company and globalize the Korean show business. Based on intense market surveys on the preferences of teenage girls, he produced idol stars that teenage consumers wanted to see. Lee worked hard to make inroads first into China and then the global market. Since its establishment in 1995, SM has always been the most renowned and influential company in the global Hallyu market as well as in the domestic market.

\section{Policy Factor: Governmental Support for Cultural Export}

The government offered a helping hand from time to time in developing an exportable Korean pop culture (Kim, 2002a). In 1995, the Korean government established a culture industry bureau within the Ministry of Culture. In 1996, the ministry started to help the Korean record industry exploit overseas markets. The ministry's department of games and records collected information about major international music fairs such as MIDEM, PORKOMM, and WOMEX. The government encouraged Korean companies 
to attend these fairs. For the first time in the history of Korean music industry, a public booth exclusively for Korean record companies was set up at overseas music fairs. The Ministry of Culture invested $¥ 42$ million for making promotional CDs and pamphlets to introduce Korean pop musicians to foreign buyers.

In 1999, the ministry made a more serious attempt to help the Korean music industry enter the overseas market by funding an interesting project to make sample K-pop CDs available for overseas distribution. The result was three compilation CDs that contained several Korean popular songs performed by original K-pop singers with the lyrics translated into Chinese, Japanese, and English. On the cover of the Chinese version CD, as shown in figure 4, the word "Hallyu" appeared in Chinese characters. Six thousand copies of this $\mathrm{CD}$ were sent out to various entertainment-related organizations in China.

Besides sponsoring domestic record companies, the Korean government also helped the Korean culture industry in other small and invisible ways. In February 2000, for example, the Ministry of Culture officially sponsored H.O.T's concert in China. At that time, it was not easy for young Korean men to travel overseas unless they had completed military service. Hallyu stars like the members of H.O.T were no exception. Park Jie-won, the ministers of culture and politically the most influential cabinet member of the Kim Dae-jung government, reportedly made an official request for a flexible application of the regulations by the Military Manpower Administration.

The Ministry of Culture took other measures to support the introduction of Korean pop music to various Asian countries (Ministry of Culture and Tourism, 2001, p. 400). For example, the ministry sponsored a music program titled Seoul Vibration on Channel 5, which is a part of Star TV that is widely broadcast across Asia. It also sponsored another music program called Listening to Korea, which was jointly produced by Woojeon Soft of Korea and CNR of China. That program was aired on Saturdays and

Figure 4. First K-Pop Promotional CDs Manufactured by the Korean Government

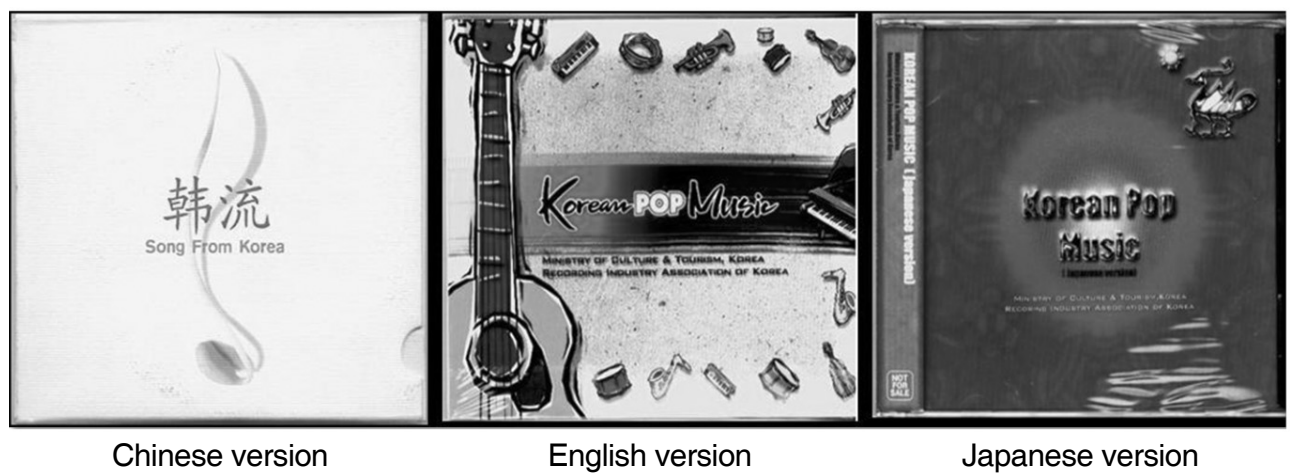


Sundays in Southeast Asian countries as well as in China. The Korean government also published various kinds of booklets in English, Japanese, and Chinese in order to introduce Korean pop music and record industry to overseas markets.

\section{Technological Factor: Expansion of Global Digital Networks}

The development of information technologies and the global expansion of digital networks contributed to the worldwide spread of Korean popular culture, especially K-pop (Davis, 2011; Samsung Economic Research Institute, 2010). If you have cultural content that you want to distribute widely, you need a route for effective and efficient delivery. Internet-based social media like blogs, YouTube, Facebook, and Twitter functioned as global superhighways by which Korean popular culture reached millions of Hallyu fans overseas. Of course, the expansion of global digital networks would be irrelevant if Korean popular culture was not itself attractive. Without such digital social networks, however, Hallyu could not have been introduced to so many audiences in such diverse areas of the world in such a short time period.

A good example is the case of Wonder Girls, one of the top idol girl groups in Korea. Their song "Nobody," released on September 22, 2008, was soon introduced to American audiences thanks to Perez Hilton, a famous American power music blogger. He happened to watch the music video of "Nobody" and found it so charming that he instantly posted it on his blog. This little event served as a momentum for the Wonder Girls, making it possible for the band to enter the American music market. In October 2009, "Nobody" finally hit number 76 on the Billboard Hot 100 chart. Because of the surprising success of this song, Wonder Girls received the honor of being the very first Korean (and fourth Asian) band ever to rank on the Billboard chart in its 120-year history.

The online buzz surrounding K-pop has become a global phenomenon. The number of viewers of K-pop music videos, for instance, jumped from about 800 million in 2010 to about 2.3 billion in 2011. The number of hits more than doubled by 2012, reaching 5 billion. Psy's "Gangnam Style" music video released on July 15, 2012, became a global super mega hit through YouTube, achieving an unprecedented record of 2.5 billion clicks in January 2016.

K-pop has certainly been one of the biggest beneficiaries of the global development of digital networks, an achievement documented by Time magazine in its August 26, 2010, issue. As the article's headline aptly puts it, "Korean Pop, with Online Help, Goes Global." According to the article,

for many artists in Korea's booming music industry, social media like YouTube and Twitter have become crucial tools to reach audiences in formerly hard-to- 
access markets like the U.S. and Europe. Korean artists are bypassing traditional outlets like radio and television, "aggressively steering their efforts to go international via the Internet," says Bernie Cho, president of DFSB Kollective, a Seoulbased agency specializing in the international marketing of Korean pop acts. "Social-media-savvy K-pop stars are now tweeting, YouTubing and Facebooking their way up music charts across and beyond Asia."

\section{SUCCESS WITHOUT DESIGN}

Although Hallyu has been called "another miracle on the Han River," there is a big difference between the cultural version and the original economic version of this miracle. Rapid economic growth and the digital revolution in Korea are good examples of government-led development. The Korean government took the initiative, playing a pivotal role throughout the whole process. It was the government that designed the policy plans, set up concrete programs, mobilized various resources, and encouraged the dubious and reluctant private sector. So the first "miracle on the Han River" was clearly a government-led success.

Foreign observers tend to see Hallyu as a product of governmental policy efforts as well, but I argue that the image of the Korean government as a vital patron of Hallyu in its early stages is largely a misperception. It is not that the government has completely stayed out of the Hallyu business, but the bits and pieces of support that it provided to enable the domestic culture industry to go abroad, some of which were even too trifling to be called "policy," were never a result of a well-coordinated effort on the part of the Korean government.

How, then, can we explain the success of Hallyu? In essence, Hallyu is an example of "success without design" (Kim, 2002a, p. 12). ${ }^{1}$ It is undeniably a miraculous achievement, but it was an unplanned and unintended success that absolutely no one, including Korean people themselves, expected. Neither government policy makers nor corporate leaders had designed any sophisticated strategic plan to achieve it. Hallyu occurred without any government or business policy.

If no one prepared any blueprint for Hallyu, then how did it come about? I argue that it was a matter of timely coincidence. The five key elements I have outlined made it possible, but importantly these factors never functioned like an orchestra; rather, they independently contributed in their own way to the success of Hallyu. Each of

1. This term was coined after the title of the book Order without Design: NII in the United States by Kramer and King (1996). 
them followed its own course, a course that was not designed according to an elaborate policy scheme under unified leadership.

The five key factors converged in the late 1990s. The coupling was not at all inevitable historically, politically, economically, or technologically. It just happened at that specific time. The competitiveness of Korean popular culture grew out of domestic political and economic circumstances in the 1980s and 1990s. The economies of China and Vietnam rapidly developed thanks to their own governmental policies within their own political and economic contexts. Korean show business entrepreneurs just tried to make money and maximize the profits. The Korean government just did what it had been doing in accordance with its own bureaucratic practices. The information technologies and digital networks that had been developed during the Second World War by US scientists for military purposes had become a very complex web of global corporate strategies and technological innovations.

Hallyu was a "surprise" (Lee, 2006, p. 247) as well as a stroke of "unexpected luck" (Park, 2005, p. 15). Out of that happenstance convergence of the five key elements sprang Hallyu. If any one of these elements had been missing, it is likely it would not have happened. Figure 5 illustrates the argument so far.

Figure 5. Hallyu, Success without Design

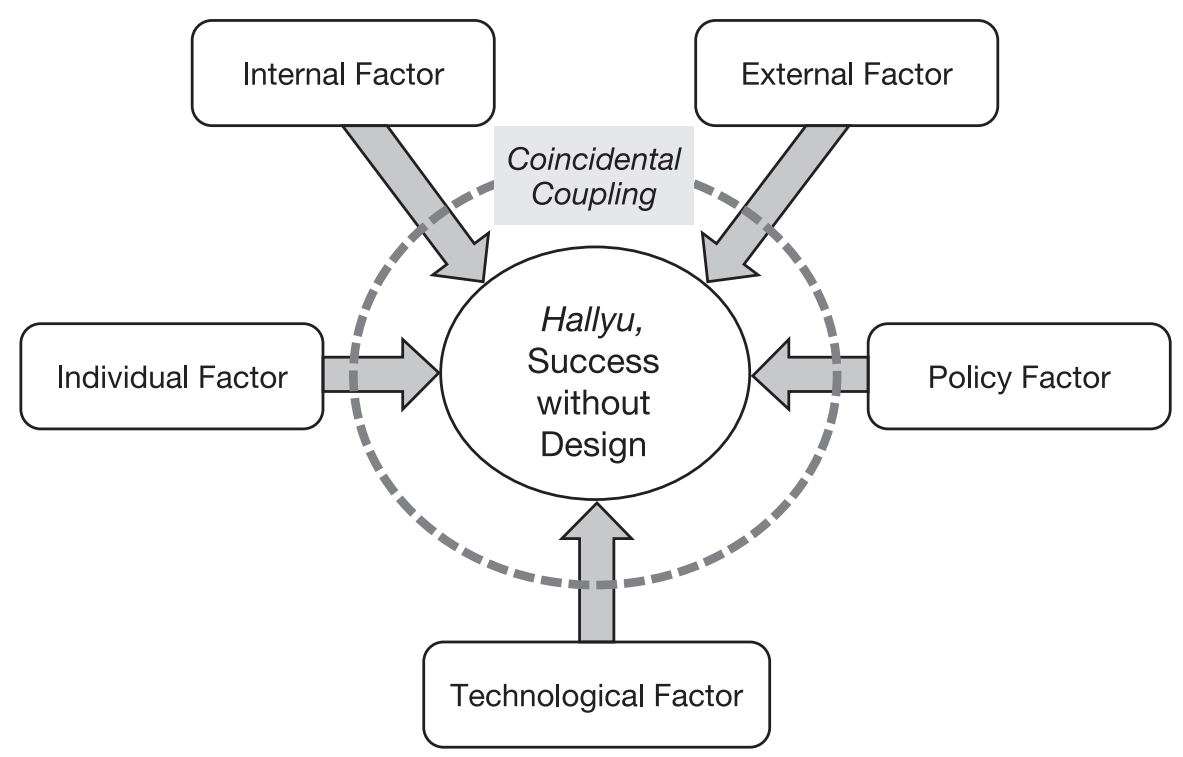




\section{Implications for Cultural Policy and Cultural Industries}

What are the implications of Hallyu for cultural policy and the culture industry? Four points deserve mentioning here.

\section{Prerequisites for Cultural Development}

The success story of Hallyu points to at least three conditions necessary for cultural progress. For one, freedom of expression is crucial in order to foster artistic creativity. The development of K-pop's competitiveness is a good example. Under the military regime that came to an end in 1992, the Korean government severely regulated and controlled popular culture in many ways. However, dance music was an exception, for it posed no threat to the authoritarian regime. Having enjoyed freedom from government surveillance, the dance music community of Korea was able to build competences. The impressive progress that the Korean film and drama industries made after deregulation in the early 1990s also indicates the importance of freedom of expression.

Second, competition motivates artists do their best, making it possible for them to produce masterpieces. Although for a long time K-pop had trouble competing with imported American and Japanese popular music, K-pop itself developed a competitive edge as a result. In the case of Korean drama, the competition for survival among domestic companies has always been very intense. The Korean film industry became competitive after a sharp increase in the import of foreign movies, especially from the United States. That surge was a consequence of a film market liberalization brought about by pressure from the U.S. government and Hollywood.

The third element is the blending of diverse cultural elements. Hybridity is the cultural essence of Hallyu (Kang, 2006; Lee, 2006; Shim, 2006). Historically, Korea was culturally dominated by China. The modern popular culture of Korea, however, has been deeply influenced by American and Japanese cultures. European culture has also influenced Korean culture, although to a lesser degree. Hallyu is not Korea's traditional culture but a mixture of various foreign cultures with the Korean spirit at the core. Multiculturalism and multinationalism established through mutual exchange and blending with other cultures seem to be the most effective way to develop cultural prosperity (Samsung Economic Research Institute, 2010; Park, et. al., 2009, p. 257).

\section{Innate Uncertainties in the World of Culture and the Arts}

The world of culture and arts is full of uncertainties. There are no royal roads to success. Even if policy makers could secure the prerequisites for cultural progress I 
have described, there is no guarantee that the policy goal would be realized.

The uncertainty is inevitable, since human emotions, which determine the fate of culture and the arts, are very difficult to logically explain and predict. There are innumerable examples in the culture industry of carefully designed projects that ended in failure. On the other hand, there are other examples of almost improvised pieces of work becoming hugely successful. Hallyu, as I have documented, was amazingly successful even though it had not been planned. The late Paik Nam-june, a world-class legend in video art, once remarked that "there can be no creation without uncertainty." It is impossible to predict exactly who will produce a masterpiece that mesmerizes the whole audiences and how they will do it.

In light of this uncertainty, a mechanistic worldview is not appropriate for cultural policy makers. They "should not believe that they can plan creativity" (Frey, 1999, p. 80). This is because, as Hirschman (1970, p. 80) aptly puts it, "creativity always comes as a surprise." When it comes to the question of the process of creativity, "no systematic pattern is evident" (Throsby, 2001, p. 105). It is little better than a myth that the greater the governmental subsidy for the arts the higher the chances of policy success (Chung, 2001, p. 4).

\section{Prince vs. Beast}

The government is not an omnipotent problem solver. Public policy fails as often as the market does (Pierce, 1981; Wolf, 1988). As Simon (1957) pointed out a long time ago, human rationality in decision making is inherently "bounded," so that decision making is possible only at a satisfactory, not optimal, level at best. Given the uncertainties in the world of culture and the arts, government capabilities are even more limited in the realm of cultural policy. The development of culture and the arts cannot be achieved through governmental control (Kim, 2007, p. 226). The magnificent success of the five-year economic development plan that brought about the first miracle on the Han river can never be expected in the realm of culture and the arts.

Therefore, we need to replace the "prince paradigm" with the "beast paradigm" (Kim, 2002b). The prince paradigm refers to the viewpoint that regards the government as a perfect problem-solver like Superman. However, such a perfect hero can be found only in fairy tales and never in the real world. In the beast paradigm, the government is a strong but boorish animal. The government may have the muscles and power to protect national security or secure public order. But it lacks the competencies and aesthetic taste needed to develop art and culture. Thus the capacity of the government to craft effective cultural policies is inherently limited.

Under the beast paradigm, one ought not expect too much from cultural policy, let 
alone perfect solutions (Kim, 2003), and the government should not stand at the forefront in the realm of culture and the arts. Policy makers should not pretend that they know what counts as good culture and art or how we can realize them. They do not the ability to foresee the future and pick out what will succeed. All that the government can, and should, do is to remove those obstacles that block the prerequisites of cultural development. Is that be enough to assure prosperity of culture and arts? Maybe or maybe not. There is no guarantee of success. After clearing away hurdles and making the ground level, the government just has to wait and see what will happen. The result of the game depends on the players, namely, the artists. One cannot blame the ground clearer, that is, the government, even if the game is lost. In fact, the responsibility of the government should also be limited in proportion to the limits of its capabilities.

\section{Cultural Policy as a Risky Venture Business}

From the preceding follows one last conclusion. Cultural policy should be regarded fundamentally as a very risky investment. The future is too uncertain to make any precise predictions. People's behavior and reactions are so volatile in the cultural as well as the stock market.

Cultural policy is thus prone to errors and failures. Of course, cultural policy makers will try to set concrete policy goals and to select the best possible means of achieving them. But no matter how hard and sincerely they try, there is no guarantee that any cultural policy will reap the harvest as expected by the policy makers. Policy makers should not be blamed for or ashamed of cultural policy failure. Rather these failures should be treated as ordinary everyday affairs of life.

That may sound too pessimistic. But Hallyu gives us a glimmer of hope. Although policy failures are inevitable, we still can expect that something miraculous may happen at any time. Even if one does not accomplish what one wanted, one may well achieve instead something more wonderful that one did not anticipate at all. Making cultural policies is like sowing seeds; one does not know in advance which one will bloom (Kim, 2008, p. 187). As often happens in the cultural realm, one big hit could generously make up for all the other failures. Hallyu proves that miracles do happen in the world of culture and the arts. If we keep sowing whatever seeds we get, maybe a few of them will turn out to be Jack's magical beans that grow so big as to reach the sky.

One may well argue, then, that there is in fact no such thing as "policy failure" in the cultural realm. All those not-very-satisfactory policies may be regarded not as failures but as nice tries. The budget invested into those unsuccessful policies may not be viewed not as losses but as tuition. Policy makers should not be blamed too harshly. No matter how disappointing the policy consequences are, they all may function as 
precious lessons and meaningful experiences. Through the accumulation of all those tries and experiences, solid cultural capital may be steadily cultivated so that a miraculous success like Hallyu will bloom someday.

\section{CONCLUSION}

This paper argues that Hallyu, another miracle on the Han river, was essentially a success without design, that no one tried strategically to initiate it. There were five key factors-internal, external, individual, policy, and technological - that happened to converge in the late 1990s to make it possible. In this sense, Hallyu was fortuitous.

The miraculous success of Hallyu has important implications for cultural policy and the culture industry. First, freedom of expression, competition, and hybridity are crucial prerequisites for cultural progress. Second, the world of culture and the arts is full of uncertainties that make a mechanistic command-and-control type of policy in applicable. Third, a fundamental shift of policy perspective is necessary from the prince paradigm to the beast paradigm, which emphasizes limited capabilities and responsibility of the government. Finally, cultural policy needs to be understood as a risky investment that is prone to failure but at the same time may bring about be unexpectedly successful.

The success story of Hallyu gives us good and bad news simultaneously. Many have urged the Korean government to enact policies that will ensure that Hallyu is sustained. It is not that certain, however, whether and to what degree government-led plans can actually achieve that goal. The beast paradigm advises us not to expect too much from cultural policies. Paradoxically, it also urges us to expect that something spectacular could happen unexpectedly. If Hallyu teaches us anything, optimism must be first on the list. Scientific cost-benefit analyses to designed to help construct rational policies may fail, but there is much more to culture and the arts than scientific calculations. Life is full of sweet surprises; miracles do happen. Hallyu seems to assure it, no matter how "unscientific" that may sound.

\section{REFERENCES}

Chung, H.-I. 2001. A critique of the political economy of cultural policy. Culture and Arts, 8: 8-14.

Davis, R. W. 2011. It's all about Seoul. Nylon, June/July.

Frey, B. S. 1999. State support and creativity in the arts: Some new considerations. 
Journal of Cultural Economics, 23(1): 71-85.

Hirschman, A. O. 1970. Exit, voice, and loyalty. Cambridge, MA: Harvard University Press.

Hitting China with lavish dancing and powerful sound: H.O.T in Beijing. 2000. Chosunilbo, March 6.

Kang, C.-G. 2006. Hallyu story by a Hallyu expert. Seoul: Ichae.

Kang, N.-H. 2007. Neoliberalism and Hallyu. Chinese Modern Literature, 42: 273-302.

Kim, J. 2008. Reflection on public support for the arts. Journal of Cultural Policy, 20: 163-191.

Kim, J. 2011. Policy lessons from the (new) Korean Wave. Korean Journal of Public Administration, 20 (3): 1-33.

Kim, S.-B. 2007. The attractiveness of Hallyu and the East Asian cultural network. World Politics, 28 (1): 192-233.

Korea Creative Content Agency. 2011. New Hallyu led by K-Pop. KOCCA Focus, March.

Korea Cultural Policy Institute. 2001. A Study of policy measures aimed at supporting the overseas expansion of Korea's culture industries: Seeking the sustainable development of Hallyu. Seoul: Korean Cultural Policy Institute.

Korean pop, with online help, goes global. 2010. Time, August 26. Retrieved on December 13, 2016, from http://content.time.com/time/world/article/0,8599, 2013227,00.html?iid=sr-link6.

Kraemer, K. L.. \& King, J. L. 1996. Order without design: NII in the United States. Information Infrastructure and Policy, 5(2): 135-168.

Lee, G.-H. 1988. A half century of Korean popular music, "hurray for independence." Gookminilbo, August 17.

Lee, H.-S. 2000. Chinese odyssey of Kim Yun-Ho, Hallyu business leader. Sindonga, October.

Lee, K.-H. 2006. The rise of transregional popular culture and the cultural politics of Hallyu. In S. Kim (ed.), Hallyu and the cultural vision of the 21st century. Seoul: Cheongdong-Geoul.

Ministry of Culture and Sports. 1997. Cultural industry. White paper.

Ministry of Culture and Tourism. 2001. Cultural industry. White paper.

Paik, W.-D. 2005. Hallyu: Cultural choice of East Asia. Seoul: Pentagram.

Park, C.-W., et. al. 2009. Glocal cultural contents: How and why. Seoul: Hankuk University of Foreign Studies Press.

Park, J.-B. 2005. Hallyu: Cultural competitiveness in the global age. SERI Research Essay.

Peirce, W. S. 1981. Bureaucratic failure and public expenditure. New York: Academic 
Press.

Ryu, J.-R. 2001. The current state and the future direction of culture industry policy. Seminar on the identity and sustainability of Hallyu. Northeast Asia Forum, held at East West Institute, Yonsei University, October 11.

Samsung Economic Research Institute. 2010. The age of new Hallyu led by idol groups. SERI Management Note 76.

Shim, D. 2006. Hybridity and the rise of Korean popular culture in Asia. Media, Culture, and Society, 28(1): 25-44.

Simon, H. A. 1976. Administrative behavior (3rd ed.). New York: Free Press.

Throsby, D. Economics and culture. Cambridge: Cambridge University Press.

Wolf, C., Jr. 1988. Markets or governments: Choosing between imperfect alternatives. Cambridge, MA: MIT Press.

Yang, S.-H. 1998. Sales of American pop song records decrease sharply with the rise of Korean popular music. Monnhwailbo, August 4.

Yoo, S.-C., et. al. 2005. The secrets of Hallyu DNA. Seoul: Tree of Thought.

Watch your Back, Bieber: The boy band is making a comeback. 2012. Time, March 9. Retrieved on December 13, 2016, http://newsfeed.time.com/2012/03/09/watchyour-back-bieber-the-boy-band-is-making-a-comeback/?iid=sr-link10. 